Фітохімічні дослідження

Phytochemical researches

Рекомендована д. фрармац. наук. профр. С. М. Марчишин

УдК 582.929.4:547.56

DOI

\title{
ДОСЛІДЖЕННЯ ФЕНОЛЬНИХ СПОЛУК РОЗХІДНИКА ЗВИЧАЙНОГО (GLЕСНОМА HEDERACEA L.)
}

\section{(C). С. Гарник}

\section{Вінницький національний медичний університет імені М. І. Пирогова}

\begin{abstract}
Резюме: у траві розхідника звичайного визначено кількісний вміст речовин френольної природи: суми гідроксикоричних кислот (4,20-6,47 \%), фрлавоноїдів (0,77-1,35 \%), окиснюваних фенолів (7,75-8,51 \%). Методом високоефективної рідинної хроматографії ідентифріковано фрлавоноїди (рутин, гіперозид, апігенін, лютеолін, ізокверцитрин), кумарини (скополетин, умбеліферон), гідроксикоричні кислоти (розмаринову, хлорогенову, косрейну, п-кумарову) та встановлено їх кількісний вміст.
\end{abstract}

Ключові слова: розхідник звичайний, фенольні сполуки, спектрофотометрія, перманганатометрія, високоесрективна рідинна хроматографрія.

Вступ. Характерною особливістю представників рослинного світу є їх здатність до синтезу та накопичення величезної кількості сполук френольної природи. Природні френоли проявляють високу біологічну активність. Вони беруть участь у різноманітних фрізіологічних процесах: диханні, фотосинтезі, рості, розвитку та репродукції рослин; деякі поліфеноли захищають рослини від патогенних мікроорганізмів та грибкових захворювань.

Лікарські препарати на основі френольних сполук широко використовують як протимікробні, протизапальні, кровоспинні, жовчогінні, сечогінні, гіпотензивні, тонізуючі, в'яжучі та проносні засоби. Більшість фенольних сполук рослинного походження малотоксичні та не проявляють побічних ефектів [4].

У попередніх дослідженнях встановлено, що трава розхідника звичайного містить значну кількість речовин фенольного характеру: гідроксикоричних кислот, фрлавоноїдів, дубильних речовин [3, 5-8]. Тому метою дослідження було визначити кількісний вміст сполук френольного характеру спектрофротометрич- ним методом та індивідуальних сполук методом високоефрективної рідинної хроматографрії (BEPX).

Методи дослідження. Визначення суми френольних сполук у перерахунку на галову кислоту проводили спектрофотометричним методом при довжині хвилі 270 нм, суми гідроксикоричних кислот - у перерахунку на хлорогенову кислоту при довжині хвилі 327 нм, суми фрлавоноїдів - у перерахунку на рутин при довжині хвилі 410 нм; суму окиснюваних френолів визначали перманганатометричним титруванням $[1,2]$.

Для розділення суми фенольних сполук трави розхідника звичайного на окремі компоненти використовували метод BEPX. Дослідження проведено на хроматографpi Agilent 1200 (США), який укомплектований проточним вакуумним дегазатором, чотириканальним насосом градієнта низького тиску, автосамплером, термостатом колонок, діодноматричним детектором, 3 використанням колонки Supelco Discovery $\mathrm{C}_{18}$.

Результати й обговорення. Результати визначення кількісного вмісту фенольних сполук у траві розхідника звичайного наведено в таблиці 1.

Таблиця 1. Кількісний вміст фенольних сполук у траві розхідника звичайного

\begin{tabular}{|l|c|c|}
\hline \multicolumn{1}{|c|}{ Фенольна сполука } & Об'єкти дослідження & Вміст БАР, \% \\
\hline \multirow{2}{*}{ Сума френольних сполук } & 1 & $3,15-3,41$ \\
\hline \multirow{2}{*}{ Сума окиснюваних френолів } & 2 & $2,98-3,29$ \\
\cline { 2 - 3 } & 1 & $8,34-8,51$ \\
\hline \multirow{2}{*}{ Сума фрлавоноїдів } & 2 & $7,75-8,14$ \\
\hline \multirow{2}{*}{ Сума гідроксикоричних кислот } & 1 & $0,87-1,35$ \\
\cline { 2 - 3 } & 2 & $0,77-1,04$ \\
\cline { 2 - 3 } & 1 & $4,20-6,47$ \\
\hline
\end{tabular}

Примітки. об'єкт № 1 - сировина, заготовлена у Тернопільській області; об'єкт № 2 - сировина, заготовлена у Вінницькій області.

ISSN 2312-0967. Фармацевтичний часопис. 2015. № 3 
Як свідчать результати, наведені в таблиці 1, вміст суми френольних сполук у траві розхідника звичайного становив 3,15-3,41 \% у об'єкті № 1 та 2,98-3,29 \% у об'єкті № 2 .

Вміст суми окиснюваних френолів у об'єкті № 1 склав 8,34-8,51 \%, у об'єкті № 2 - 7,75-8,14\% .

Кількісний вміст суми фрлавоноїдів у траві розхідника звичайного становив: 0,87-1,35 \% та 0,77-1,04\%; суми гідроксикоричних кислот - 4,20-6,47 \% та 4,846,36 \% відповідно для об'єктів № 1 та № 2.

Методом ВЕРХ було виявлено, ідентифіковано та встановлено кількісний вміст індивідуальних фенольних сполук у траві розхідника звичайного (рис. 1-4). У досліджуваних об'єктах № 1 та № 2 ідентифріковано фрлавоноїди (рутин, гіперозид, апігенін, лютеолін, ізо- кверцитрин), кумарини (скополетин, умбеліферон), гідроксикоричні кислоти (розмаринову, хлорогенову, кофейну, п-кумарову) та визначено їх кількісний вміст. У об'єкті № 1 не виявлено кофейної і п-кумарової кислоти, умбеліферону.

Серед сполук фрлавоноїдної природи розхідника звичайного найбільша кількість припадала на рутин - 0,40 і 0,23 \% відповідно в об'єктах № 1 та № 2. 3 гідроксикоричних кислот у об'єкті № 2 спостерігали значний вміст розмаринової кислоти - 1,13 \%. Вміст хлорогенової кислоти також був значним і становив у досліджуваних об'єктах 0,84 \% (№ 1) та 0,81 \% (№ 2). Результати кількісного вмісту фенольних сполук у траві розхідника звичайного представлено у таблиці 2.

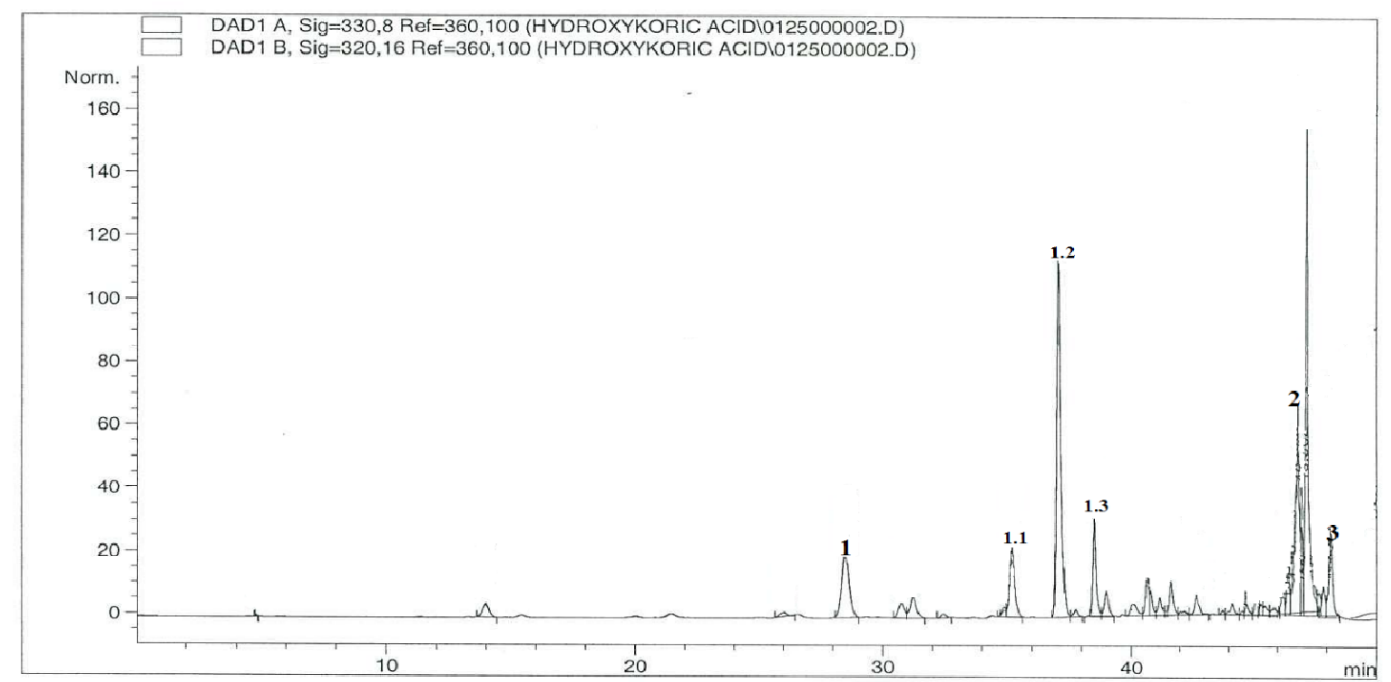

Рис. 1. Хроматограма гідроксикоричних кислот та кумаринів об'єкта № 1 при $\lambda=330$ нм: 1 - хлорогенова кислота (1.1, 1.2, 1.3 - ізомери), 2 - скополетин, 3 - розмаринова кислота.

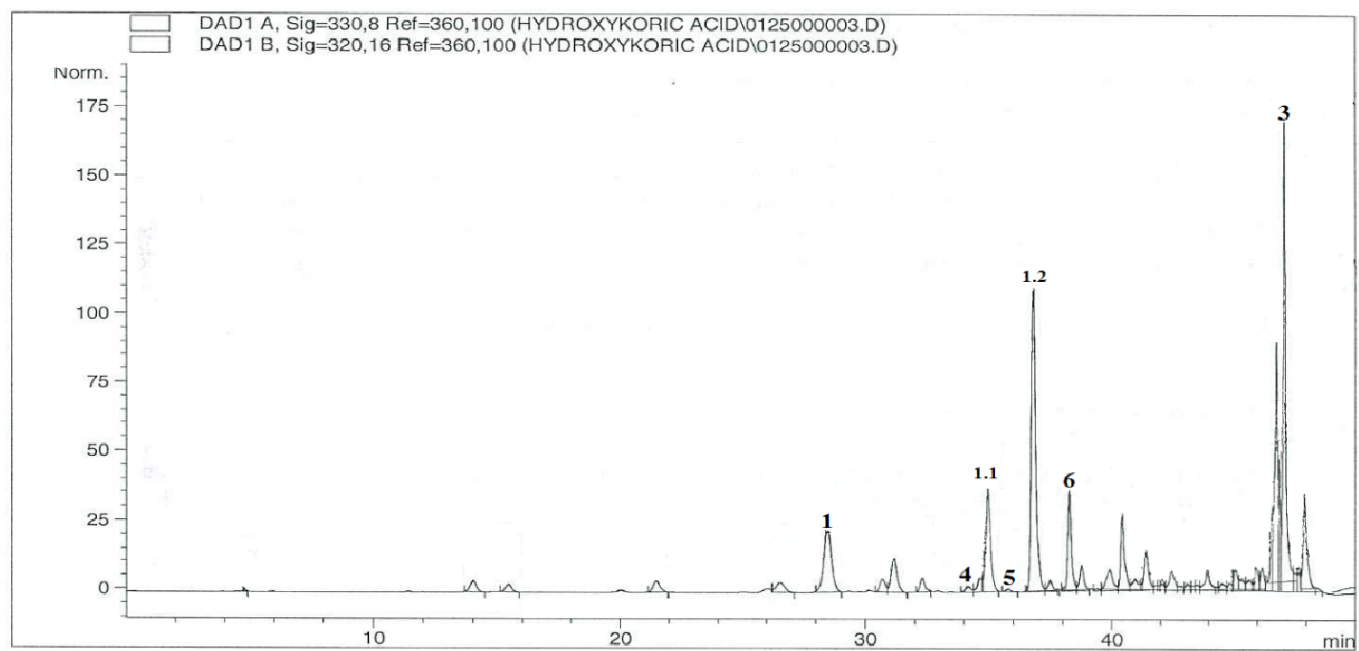

Рис. 2. Хроматограма гідроксикоричних кислот та кумаринів об'єкта № 2: при $\lambda=330$ нм: 1 - хлорогенова кислота

(1.1, 1.2 - ізомери), 3 - розмаринова кислота; при $\lambda=320$ нм: 4 - умбеліферон, 5 - п-кумарова кислота, 6 кофейна кислота.

ISSN 2312-0967. Pharmaceutical review. 2015. № 3 


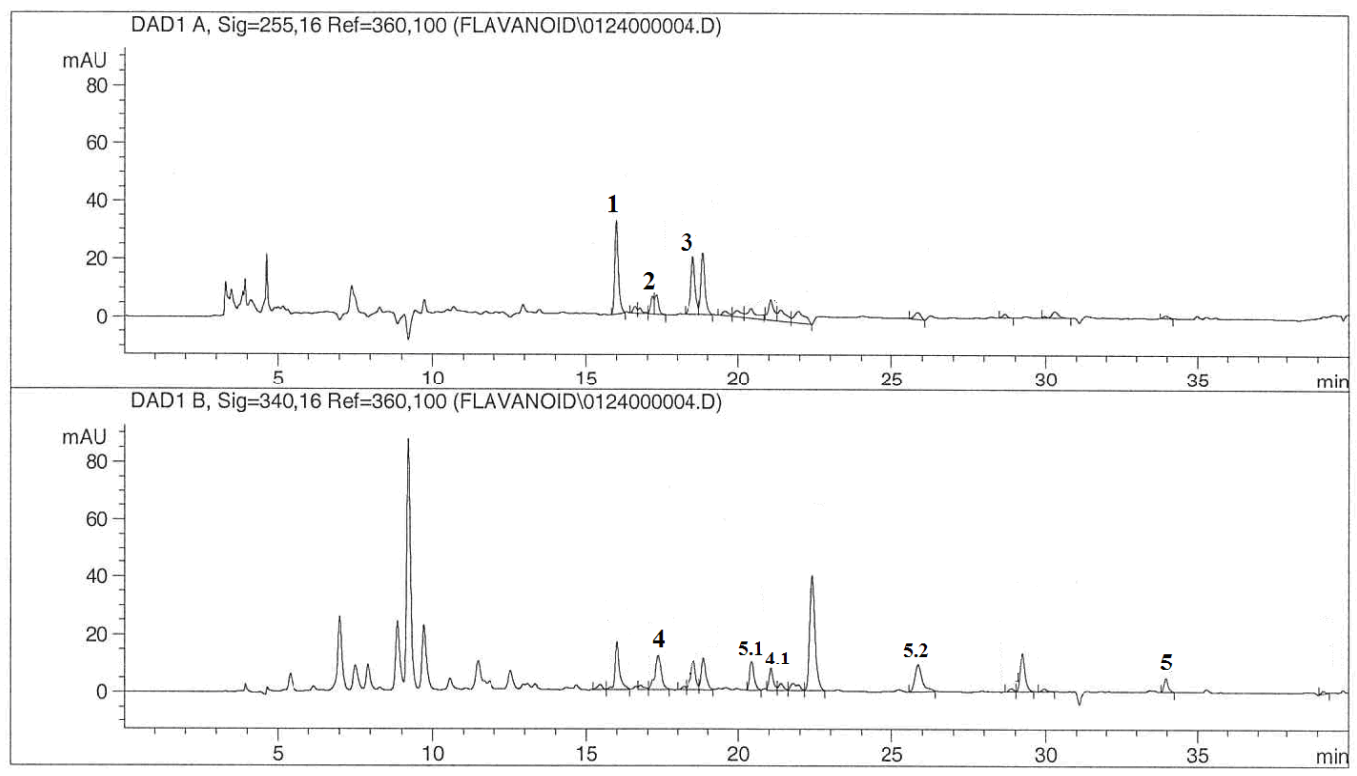

Рис. 3. Хроматограма фрлавоноїдів об'єкта № 1:

при $\lambda=255$ нм: 1 - рутин , 2 - ізокверцитрин, 3 - гіперозид;

при $\lambda=340$ нм: 4 - лютеолін, 5 - апігенін (4.1, 5.1, 5.2 - відповідні глікозиди).

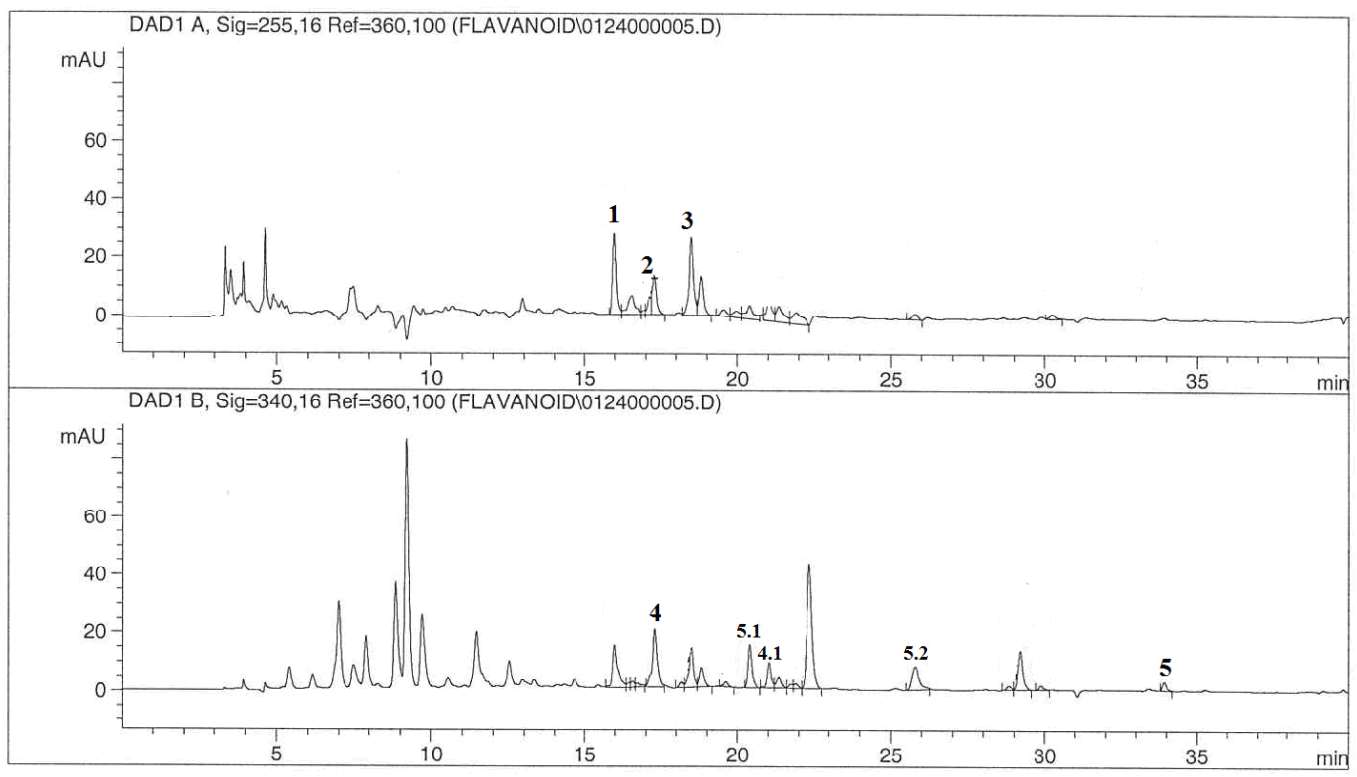

Рис. 4. Хроматограма фрлавоноїдів об'єкта № 2:

при $\lambda=255$ нм: 1 - рутин , 2 - ізокверцитрин, 3 - гіперозид;

при $\lambda=340$ нм: 4 - лютеолін, 5 - апігенін (4.1, 5.1, 5.2 - відповідні глікозиди). 
Фітохімічні дослідження Phytochemical researches

Таблиця 2. Вміст френольних сполук у траві розхідника звичайного (метод BEPX)

\begin{tabular}{|l|c|c|}
\hline \multirow{2}{*}{\multicolumn{1}{|c|}{ Речовина }} & \multicolumn{2}{c|}{ Вміст } \\
\cline { 2 - 3 } & об'єкт 1 & 0,23 \\
\hline Рутин & 0,40 & 0,34 \\
\hline Гіперозид & 0,17 & 0,06 \\
\hline Апігенін & 0,06 & 0,10 \\
\hline Лютеолін & 0,05 & 0,03 \\
\hline Ізокверцитрин & 0,02 & 1,13 \\
\hline Розмаринова кислота & 0,20 & 0,81 \\
\hline Хлорогенова кислота & 0,84 & 0,06 \\
\hline Косрейна кислота & - & 0,18 * $10^{-4}$ \\
\hline п-кумарова кислота & - & 0,12 \\
\hline Скополетин & 0,11 & 0,02 \\
\hline Умбелісрерон & - & \\
\hline
\end{tabular}

Висновки. 1. У досліджуваних об'єктах розхідника звичайного визначено кількісний вміст речовин фенольної природи: суми окиснюваних фенолів, суми гідроксикоричних кислот, суми фрлавоноїдів.

Методом високоефективної рідинної хроматографрії було ідентифріковано та встановлено кількісний вміст орлавоноїдів (рутину - 0,23-0,40 \%, гіперозиду - 0,17-0,34 \%, лютеоліну - 0,05-0,1\%, ізокверцитрину - 0,02-0,03 \%, апігеніну 0,06 \%), гідроксикоричних кислот (хлорогенової - 0,81-0,84 \%, розмаринової 0,2-1,13\%, кофрейної - 0,06 \%, п-кумарової - сліди) та кумаринів (скополетину - 0,11-0,12 \%, умбеліферону $-0,02 \%)$.

\section{Список літератури}

1. Болоховець Г. С. Вивчення фенольних сполук у траві розторопші плямистої / Г. С. Болоховець, В. С. Кисличенко // Медична хімія. - 2004. - 6, № 4. - С. 18-22. 2. Государственная фрармакопея СССР. Вып. 1. Общие методы анализа / М3 СССР. - 11-е изд., доп. - М. : Медицина, 1990. - 336 с.

3. Василенко Е. А. Исследование френольных соединений будры плющевидной (Glechoma hederacea L.), выращенной в условиях Северного Кавказа / Е. А. Василенко, О. И. Попова // Научные ведомости Белгородского государственного университета. Медицина. Фармация. - 2012. - № 16 (135), вып. 19. С. $170-172$.

4. Маркарян А. А. Хроматографрическое изучение френольного состава сухого экстракта «Нефррофит» / А. А. Маркарян, А. А. Абрамов // Вестник Московского университета. Серия 2. «Химия». - 2003. - Т. 44. № 5.

- C. 356-360.

5. Изучение химического состава травы будры плющевидной и разработка на ее основе лекарственной формы/И. Д. Писарев, О.О. Новиков, А. С. Шабельникова [и др.] // Современные проблемы науки и образования. - 2012. - № 4 (42). - Режим доступа : [www. scienceeducation.ru/104-6666].

6. Товстуха Є. С. Золоті рецепти української медицини / €. С. Товстуха. - K. : Publishing, 2010. - 552 c.

7. Milovanovic M. Antioxydant effects of Glechoma hederacea as a food additive / M. Milovanovic, D. Zivkovic, B. Vucelic-Radovic // Nat. Prod. Commun. - 2010. - № 5 (1). - P. 61-63.

8. Two new glycosides from the whole plants of Glechoma hederaceae L. / H. Yamauchi, R. Kakuda, Y. Yaoita [et al.] // Chem. Pharm. Bull (Tokyo). - 2007. - № 55 (2). - P. 346347.

\section{ИССЛЕДОВАНИЕ ФЕНОЛЬНЫХ СОЕДИНЕНИЙ БУДРЫ ПЛЮЩЕВИДНОЙ (GLЕСНОМА HEDERACEA L.)}

\section{М. С. Гарник}

Винницкий национальный медицинский университет имени Н. И. Пирогова

Резюме: в траве будрыплющевидной определено количественное содержание веществ фенольногопроисхождения: суммы гидроксикоричных кислот (4,20-6,47 \%), фрлавоноидов (0,77-1,35 \%), окислительных фенолов (7,75-

ISSN 2312-0967. Pharmaceutical review. 2015. № 3 
Фітохімічні дослідження

Phytochemical researches

8,51 \%). Методом високоэффрективной жидкостной хроматографрии идентифрицировано фрлавоноиды (рутин, гиперозид, апигенин, лютеолин, изокверцитрин), кумарины (скополетин, умбелисерон), гидроксикоричные кислоти (розмариновую, хлорогеновую, кофейную, п-кумаровую) и установлено их количественное содержание.

Ключевые слова: будра плющевидная, френольные соединения, спектрофротометрия, перманганатометрия, высокоэффрективная жидкостная хроматограсия.

\section{THE INVESTIGATION OF COMPOUNDS PHENOL ORIGIN GROUND IVY (GLECHOMA HEDERACEA L.)}

\section{S. Harnyk}

\section{I. Pyrohov Vinnytsia National Medical University}

Summary: compounds of phenol origin have been quantified in ground ivy herb, they are hydroxycinnamic acids (4.20$6.47 \%)$, flavonoids (0.77-1.35\%), oxidized phenols (7.75-8.51\%). Flavonoid groups (rutin, hyperozide, apigenine, luteolin, isoquercitrin), coumarines (scopoletin, umbelliferone) hydroxycinnamic acids (rosmarinic, chlorogenic, caffeic, p-coumaric) have been identified by the method of HPLC and their content has been identified.

Key words: ground ivy, compounds of phenol origin, spectrophotometry, permanganatometry, high performance liquid chromatography.

Отримано 08.05.2015

ISSN 2312-0967. Фармацевтичний часопис. 2015. № 3 